\title{
Editorial Anthrovision issue 3.1
}

\section{Beate Engelbrecht}

\section{(2) OpenEdition \\ Journals}

Electronic version

URL: http://journals.openedition.org/anthrovision/1570

DOI: 10.4000/anthrovision. 1570

ISSN: 2198-6754

\section{Publisher}

VANEASA - Visual Anthropology Network of European Association of Social Anthropologists

\section{Electronic reference}

Beate Engelbrecht, «Editorial Anthrovision issue 3.1 », Anthrovision [Online], 3.1 | 2015, Online since 16 November 2015, connection on 24 September 2020. URL : http://journals.openedition.org/ anthrovision/1570 ; DOI : https://doi.org/10.4000/anthrovision.1570

This text was automatically generated on 24 September 2020

(c) Anthrovision 


\title{
Editorial Anthrovision issue 3.1
}

\author{
Beate Engelbrecht
}

Dear reader,

2 AnthroVision is now in its third year. After publishing two issues in 2014 that concentrated on special topics, the current issue contains a variety of contributions which all discuss methodological questions. As our editorial policy has not required each article to contribute to theoretical and academic debates, we have also started two new sections which are not peer-reviewed but which give the authors the freedom to write more creatively, or to initiate discussions on methodological topics.

3 The volume starts with the extraordinary account of an ethnographic filmmaker who experienced a personal tragedy during her film work which brought her closer to the people she was working with. Ella Pugliese's article "Under a Blue Sky" tells how she and her husband started a participatory video project on trauma in Cambodian villages. They integrated the people in their work and encouraged them to tell their stories through paintings and re-enactments. Not long before the end of the project, her husband was killed in accident, leaving Ella to face her loss and go through its traumatic aftermath. This process gradually gave her a completely new perspective on their participatory video work. Ella's account was so exceptional that we decided to publish it in two parts in the same volume.

4 Shotaro Wake writes also about suffering in his article "Approaching Fluid Silence in the Context of Cancer in Japan - Visual Microanalysis on the Ethnographic Film, Ippo Ippo (2010)". Here he reanalyses a film he made previously in greater depth to understand better how people in Japan communicate -- or not - their illnesses and suffering. Wake concentrates on various methodological questions as the communications are not expressed verbally but by other means. Silvio Carta also discusses methodological questions in his article "Visual and Experiential Knowledge in Observational Cinema". He re-examines observational filmmaking methodologies in the context of postmodern anthropology. Concentrating on the coincidences which are fundamental in this style of filmmaking, he discusses how the whole film process leads to a consistent film construction. He then discusses how observational cinema 
represents a way of exploring new territory in the production of experiential knowledge.

Izai Amorim's article "The Lace Curtains of Berlin" tells us about his observations of lace curtains in Berlin from a communicative point of view. He thinks about what these lace curtains might communicate to whom, what their purposes are. His article is published in the new AnthroVision Research and Experimental Section which encourages authors to express their ideas not academically but in more creative ways. Amorim mixes his systematic observations with free associations, and introduces a fictitious person to reflect on these lace curtains and the nature of the investigations best suited to understand them.

6 Felicia Hughes-Freeland's article "The Importance of Ethnographic Film/Video/ Multimedia in the Development and Assessment of Anthropological Understanding" starts another new AnthroVision Section called Discussion. In this section authors can contribute articles which are more general observations and ideas about the visual in anthropology and which are not peer-reviewed. Hughes-Freeland discusses her project about how to assess ethnographic film and the production of CD-ROMs in undergraduate anthropology degrees at the beginning of the twenty-first century, and what her research, as 15 years later the assessment of non-verbal work within academic degrees remains controversial.

\section{AUTHOR}

\section{BEATE ENGELBRECHT}

Director of Anthrovision 